\title{
Explaining Structural Constraints on Lay Participation in Field Science
}

\author{
Jeremy Vetter, University of Arizona
}

\begin{abstract}
Using an example from the author's work on field science in the American West in the early twentieth century, this essay considers how structural constraints on the interactions between scientists and lay people in the field might be explained. Not only is there unusually abundant source evidence about a local ranching family living near a paleontological field site, but the Cooks were especially assertive in attempting to exert influence. This example functions as a thickly documented limiting case for testing the constraints on lay participation in field practice during this period.
\end{abstract}

$\mathrm{T}$

he Cooks were a settler colonial ranching family, accustomed to having a great deal of autonomy and authority to shape their immediate environment. In 1904, when visiting scientists from the Carnegie Museum of Pittsburgh began to take an intense interest in the fossil hills a few miles east of their ranch home, in the Niobrara Valley in Nebraska, they were eager to be involved in supporting science. But it became clear over the ensuing years that they expected to have influence over such things as how the land was managed, how credit was given for the discoveries, and (later on) where the materials that were uncovered would end up being displayed. While in the early years they promoted a free and open approach, welcoming and supporting any and all museums, and expressed little concern as to where those materials might be taken, over the next decade or two the Cooks began to ask for more. ${ }^{1}$

Like many others who study the field sciences, I have long been interested in the participation, around sites of scientific fieldwork, of local people who collaborated with visiting scientists or engaged in conflict with them or both. But when we do encounter examples of such participation, how can we avoid flattening the social world, so that the very existence of collaboration or conflict becomes the whole story? How can we further analyze the power relations inherent when lay people participate in science, in order to go beyond the mere statement that local people were there and did something to exert influence? ${ }^{2}$

\footnotetext{
Jeremy Vetter is an associate professor of history at the University of Arizona. He is the author of Field Life: Science in the American West during the Railroad Era (Pittsburgh, 2016) and the editor of Knowing Global Environments: New Historical Perspectives on the Field Sciences (Rutgers, 2011). Department of History, Chavez Room 415, 1110 James E. Rogers Way, Tucson, Arizona 85721, USA; jvetter@email.arizona.edu.

${ }^{1}$ Jeremy Vetter, "Cowboys, Scientists, and Fossils: The Field Site and Local Collaboration in the American West," Isis, 2008, 99:273-303.

${ }^{2}$ For just a few of the many notable recent works see Nancy J. Jacobs, Birders of Africa: History of a Network (New Haven, Conn.: Yale Univ. Press, 2016); Deborah R. Coen, The Earthquake Observers: Disaster Science from Lisbon to Richter (Chicago: Univ. Chicago Press, 2013); Conevery Bolton Valencius, The Lost History of the New Madrid Earthquakes (Chicago: Univ. Chicago Press, 2013); and Jim Endersby, Imperial Nature: Joseph Dalton Hooker and the Practices of Victorian Science (Chicago: Univ.
}

Isis, volume 110, number 2. (C) 2019 by The History of Science Society.

All rights reserved. 0021-1753/2019/0110-0015\$10.00. 
When I first embarked on the research that led to my recent book, Field Life: Science in the American West during the Railroad Era, I knew that I wanted to look for source materials that would allow a deeper examination of the structure of scientific participation, beyond simply stating that people were there-both colonizing settlers and American Indians - and that they played some role in the story. ${ }^{3}$ I knew that I wanted to find out how fieldwork was experienced not just by the visiting field scientists but also by local people who lived in the areas where they did their work. In examining the locals' participation, however, I did not just want to uncover the opportunities for influencing the situation but also to account for the limitations and constraints on their influence. I wanted to explain the structural conditions of their involvement by looking at what they tried to do, what they were able to achieve, and what they could not accomplish. But how to find a thoroughly developed and rich body of evidence for this?

The key methodological problem in trying to probe lay participation in science is that most local people are unlike visiting field scientists, who often leave behind substantial collections of letters and other documents to provide evidence of their lives and careers, especially if they are reasonably famous - and sometimes even if they are not! Most lay participants do not leave such materials, and even if they do their pertinent observations are often scattered and intermixed with many other concerns in their letters and diaries-since, after all, they typically had complex, multifaceted lives and careers apart from their collaborations and conflicts with visiting scientists. So it was with great excitement that I discovered the collection of papers of the Cook ranching family held at the Agate Fossil Beds National Monument, in the remote northwest corner of Nebraska. This collection provided a perspective on field science that came from the local people and was organized to reflect their own view of the world.

I found this collection of documents so useful, in fact, that I wrote up a stand-alone journal article for Isis, published in 2008, that was based primarily on the Agate Fossil Beds case study, even as I incorporated a small amount of evidence from this field site into the larger and more broadly ranging project that culminated in Field Life. ${ }^{4}$ In this article, I attempted to explain both the leverage that the Cook family had at the site and the structural constraints that limited how much they could accomplish their own objectives. I am now working on a book-length version of my story about the Cook family and their interactions with visiting scientists, which I am styling as a "biography of a scientific field site." As I expand the story to tell it more fully than I was able to do in a single article, it is an opportune time for me to consider how my explanation works in this case study.

One obvious challenge is to consider the Agate Fossil Beds story as an explanation of anything larger than itself, since it would be easy to point out that it is but a single case and that the people involved might be atypical or different from other lay people who lived and worked near other field sites. This is a complication that faces all local histories of science, even as we have now had several decades of interest in - even, some might say, valorization of-deeply contextualized and locally situated accounts in the history of science. We cannot ever fully escape this critique, and in fact that was a major reason why I framed my larger Field Life project as a regional study encompassing all field science in the region from the 1860s to the 1910s, rather than focusing on just one or a small number of specific local examples. Yet I did make a larger argument from local materials in my Isis article, and I intend to adopt such a microhistorical

Chicago Press, 2008). For citations to more of this scholarly literature as of eight years ago see my introductory essay to "Lay Participation in the History of Scientific Observation," special issue, Science in Context, 2011, 24:127-141. Other articles in that special issue are by Jenny Beckman, Brita Brenna, Victoria Cain, Emmanuel Didier, Oliver Hochadel, and Simon Werrett. ${ }^{3}$ Jeremy Vetter, Field Life: Science in the American West during the Railroad Era (Pittsburgh: Univ. Pittsburgh Press, 2016).

${ }^{4}$ Vetter, "Cowboys, Scientists, and Fossils" (cit. n. 1). 
approach for the follow-up book on the Agate Fossil Beds as well. I think there is still a great deal to be learned from such studies, but I do willingly concede that sound arguments must be offered to warrant drawing larger conclusions from specific local projects, however rich and suggestive the archival evidence may be. In the case of the Agate Fossil Beds, my argument was, and is, that it provides a suitable test for the limits and constraints faced by local people in trying to influence the practice of field science, precisely because the Cook family was so unusual in their determination to exert their influence and evident willingness to push against various barriers that seemed to constrain them.

Certainly the family had leverage over some things, and part of the explanation I have offered about the power relations of field science in the early twentieth century involves a recognition that some things could be influenced and changed by the actions of local people who lived around field sites. In the case of the Agate Fossil Beds, the Cook family deftly exploited the land laws to their advantage in order to gain formal ownership over the richest fossil hills, which were located just beyond their own property lines. As ranchers, they were not only well versed in the mechanisms for controlling land areas larger than a homestead permit (even a 640-acre Kinkaid Act claim, as was uniquely allowed in western Nebraska) but also knew how to focus land claims on strategic resources such as water (or, in this case, fossils). Local people like the Cooks not only had access to control over land but often controlled scarce labor resources in a sparsely populated area as well; they also had experiential knowledge of the landscape, which visiting scientists did not possess, regarding where promising fossil exposures might be found throughout the entire area. These advantages were used by the Cooks to accomplish some of what they wanted.

However, the other, and perhaps more important, part of my explanation of the social structural conditions of field science involves using the rich collection of letters and other documents in order to show how even a highly motivated and assertive ranching family could not achieve everything they wanted. Here is but a thumbnail sketch of a few key points where the archival evidence reveals that the ambitions of the Cook ranching family to influence field science were frustrated. The most intense conflicts with the Carnegie Museum arose from the Cooks' attempts to claim discovery rights over the site. This involved both a priority claim that they-especially the father, James Cook -insisted on having respected in the published scientific literature and the requirement that the family maintain the role of key ground-level enablers of scientific practice who could graciously, and with reciprocal social benefits, allow visiting scientists from different institutions to work there. Yet the Cooks found these ambitions frustrated. They managed to gain some limited formal credit, in publications, for their discovery - but only by asking the American Museum of Natural History in New York, whose field representatives followed the Carnegie Museum workers to the site within a few years, to make this priority claim on their behalf. In return, they effectively gave up the right to offer free and open access to other museums, leaving the American Museum privileged access to the site.

Moreover, after watching railcar loads of Miocene fossils transported away for processing and description elsewhere, the Cooks wanted, eventually, to set up their own exhibition space, and they encouraged the American Museum to fund it as a local outpost. By this point the family's son, Harold, now a young man, had been invited to go to the American Museum for training and education; nonetheless, his wider ambitions to combine ranch management with paleontology were only partially and intermittently realized on the site, owing to the structural constraints that this case study reveals. In all of these examples, I use the Cook family's own rich and detailed writings to explain how structured power relations shaped lay participation in field science. 